\title{
TUBERKULIOZĖS DIAGNOSTIKOS IR GYDYMO TAKTIKA
}

\author{
DR. VIDA BUTKUVIENE \\ KMU PULMONOLOGIJOS IR IMUNOLOGIJOS KLINIKA, \\ KMUK FILIALAS ROMAINIŲ TUBERKULIOZĖS LIGONINE்
}

\begin{abstract}
Reikšminiai žodžiai: tuberkuliozės diagnostika, tuberkuliozės gydymas.
Santrauka. Išsiaiškinant tuberkulioze (TB) sergančius asmenis labai svarbus vaidmuo tenka bendrosios praktikos (šeimos) gydytojams. Susirgimo TB tikimybę didina nepalankūs socialiniai veiksniai, žalingi ịpročiai, lètinės ligos, kitos infekcijos, nepakankama mityba. TB diagnozès patvirtinimo esmè - TB diagnostikos kriterijų jvertinimas. Pagrindinis dèmesys skiriamas etiologinei diagnostikai ir tiesiogiai kontroliuojamam gydymui. Tuberkuliozės diagnostikos ir gydymo procese turi dalyvauti įvairių specialybių gydytojai: ftiziatrai, pulmonologai, internistai, o ypač bendrosios praktikos gydytojai. Tinkamas TB gydymas - tai pagrindinė tuberkuliozės profilaktikos priemonè. Tiesiogiai kontroliuojama gydymo strategija yra pagrindinė TB gydymo strategja, pagrįsta etiologine TB diagnostika ir stantartizuota chemoterapija.
\end{abstract}

Lietuvoje i̇diegus tiesiogiai kontroliuojamo gydymo strategiją (TKGS) (angl. directly observed tretment strategy) pasikeitė požiūris ì tuberkuliozès diagnostikos ir gydymo principus. Daugiausia dèmesio kreipiama $i$ etiologinę diagnostiką, t. y. tuberkuliozès sukẻlèjo radimą, ir tiesiogiai kontroliuojamą standartizuotą gydymą. TB diagnostikos ir gydymo proceso sèkmè priklauso nuo bendro komandinio darbo, kuriame dalyvauja specialistai, gydytojai pulmonologai bei internistai, ir bendrosios praktikos gydytojai. Naujai TB susirgę asmenys išsiaiškinami pasyviu metodu, kai dèl nusiskundimų kreipiasi ì gydytoją, taigi čia labai svarbus bendrosios praktikos (šeimos) gydytojo vaidmuo [2]. Šeimos gydytojas turi:

- žinoti, kada reikia ịtarti TB;

- siųsti pas pulmonologą ištirti skreplių dèl rūgštims atsparių bakterijų (RAB);

- žinoti, kokie yra TB diagnostikos kriterijai.

Dažniausiai pasireiškiantys plaučių tuberkuliozès simptomai - kosulys ir skrepliavimas, kartu paprastai būna padidejusi kūno temperatūra, prakaituojama naktị, mažeja svoris. Nurodoma, kad stiprios ekonomikos šalyse 4-10 proc. suaugusiųjų kreipiasi ị ambulatorines medicinos ịstaigas dèl ilgiau kaip 2-3 savaitès užsitęsusio kosulio [6]. Tuberkuliozès diagnozavimo dažnumas esant lètiniam kosuliui priklauso nuo tuberkuliozès paplitimo vietoveje. Šalyse, kur sergamumas tuberkulioze mažas, lètinis kosulys gali būti sukeltas kitų priežasčių. Priešingai, Lietuvoje, kur sergamumas TB yra gana didelis, lètinio kosulio atveju TB reikètu itarti pirmiausia. Deja, pacientai, varginami kvejpavimo takų simptomų, ne visada ištiriami dèl TB. Jei Atme- tama galimybė anksti nustatyti TB, ji progresuoja iki sunkių formų, sudaromos sąlygos tuberkuliozès mikobakterijoms plisti visuomeneje.

PSO kovos su TB rekomendacijose nurodoma, kad TB reikia ittarti, kai:

- yra klinikinių simptomų (bendrųjų ir lokalių);

- yra (buvo) kontaktas su asmeniu, sergančiu TB;

- yra nepalankių veiksnių: nepakankama mityba, žalingi ipročiai, lètinès ligos, užsikrètimas TM per dvejus paskutinius metus, amžius - iki 45 metu ar daugiau kaip 65 metų [2].

\section{TB DIAGNOSTIKOS PAKOPOS}

\section{Ligos anamnezè}

Būtina išsiaiškinti, ar pacientas turèjo (turi) kontaktą su TB sergančiu asmeniu, ar anksčiau sirgo TB, ar buvo užsikrètęs, kokie ligos simptomai. Neabejotinai svarbūs rizikos veiksniai yra narkomanija ir alkoholizmas, ŽIV ir AIDS, ilgalaikis gydymas gliukokortikosteroidais ir imuninę sistemą slopinančiais vaistais, inkstų nepakankamumas, žarnyno ligos, - cukrinis diabetas, mažas kūno svoris.

\section{Tuberkulino mėginiai}

Tuberkulino mėginiais nustatomas užsikrėtimas TM. Apie 20 proc. TB sergančių ligonių reakcija ị tuberkulino méginị būna neigiama. Tačiau esant tuberkuliozei būdingų simptomų, pacientai turi būti ištirti dèl TB, nesvarbu, koks tuberkulino méginio rezultatas. Jei tuberkulino méginys teigiamas, tiriama dèl TB.

\section{Rentgeninis tyrimas}

Pokyčiai rentgenogramoje padeda ịtarti TB, bet rentgeninis tyrimas nèra diagnozę patvirtinantis metodas. 
Pirminė TB - būdinga pokyčiai (infiltratas) viduriniame ar apatiniuose laukuose su „takeliu“ i šaknị, adenopatija. Antrinè TB - pokyčiai telkiasi viršutinėse skiltyse, būdingos kavernos. Esant imunosupresijai - pokyčiai apatinèse skiltyse, diseminacija, nebūdingos kavernos.

\section{Bakteriologinis tyrimas}

Pacientų bakteriologinis ištyrimas - tai tepinèlių mikroskopija, kultūros auginimas, mikobakterijų identifikavimas ir jautrumo vaistams testas. Skreplių mikroskopija RAB nustatyti yra greitas ir pigus tyrimo būdas. Skrepliu tyrimas RAB nustatyti rekomenduojamas šiais atvejais:

- esant ilgalaikiam kosuliui (besitęsiančiam ilgiau nei 3 sav.), kai atkosima skreplių ar kraujinguc skrepliuc bei skauda krūtinę;

- užsitęsus pneumonijai (nepaisant gydymo) ar įtarus netipinę pneumoniją;

- esant TB simptomuc ir kontaktui su TB ligoniu;

- esant TB būdingų pokyčiuc plaučių rentgenogramose [2].

\section{Tepinèliu vertinimo kriterijai}

Neigiamas rezultatas

- Užsikrètimas mažiau tikètinas;

- Nepaneigia TB diagnozès.

\section{Teigiamas rezultatas}

- RAB gali būti ir ne TM;

- Epidemiologiniu požiūriu labai pavojingas kontingentas.

Kultūros vertinimo kriterijai Neigiamas rezultatas

- Nerandama gyvų TM;

- Nepaneigia TB diagnozès.

Teigiamas rezultatas

- Patvirtinta TB diagnozę.

\section{Pagrindiniai TB diagnostikos kriterijai}

1. Pirmą kartą diagnozuota TB - anksčiau nedokumentuota bei negydyta vaistais nuo tuberkuliozès arba gydyta ne ilgiau kaip vieną mènesí, kai yra vienas iš šių kriterijų:

- skreplių tepinèliuose ar kitoje tiriamoje medžiagoje rasta $\mathrm{RAB}$;

- histologiniame pažeisto organo preparate yra TB būdingu pokyčių;

- iš tiriamos medžiagos išauginami TB sukèlèjai (TM).

2. Jei mikroskopinių ar/ir bakteriologinių tyrimų rezultatai neigiami, bet yra visi TB būdingi kvėpavimo takų (naujai prasidejęs kosulys, skrepliavimas, trunkantis ilgiau kaip 3 savaites, skausmas krūtinejje) ir/ar intoksikacijos (karščiavimas, prakaitavimas, svorio mažejjimas) simptomai, kartu esant TB būdingu pokyčiuc rentgenogramose bei teigiamam tuberkulino méginiui, paciento gydymo vaistais nuo tuberkuliozès klausimas sprendžiamas individualiai kiekvienu atveju [2].
Kai skreplių mikroskopijos rezultatai neigiami, PSO rekomenduoja vadovautis bakterioskopiškai neigiamos TB diagnostikos algoritmu (1 pav.).

\section{TB GYDYMAS}

Gydant TB sergantị žmogų, siekiama trijų pagrindinių tikslų:

- išgydyti ligonį;

- užkirsti kelią formuotis atsparioms TB mikobakterijų padermèms;

- apsaugoti visuomenę nuo TB.

Gydymo taktikos parinkimas pagal aprobuotas PSO schemas - pulmonologo ar ftiziatro kompetencija. Bendrosios praktikos gydytojai organizuoja specialistuc atsiųstų TB ligonių tiesiogiai kontroliuojamą gydymą ir yra už ji atsakingi [2]. Pagal tarptautinius gydymo standartus TB chemoterapijos kursas turi būti ne trumpesnis kaip 6 mènesiai $[2,3,4,5]$, bet TB proceso atkryčio atveju TB chemoterapija taikoma ne 6, o 8 mèn., atsparios TB atveju - net 18 mèn. ir ilgiau. Tam tikromis aplinkybėmis, būtent kepenų, inkstų ligų, nẻštumo, ŽIV infekcijos atvejais, TB gydymo standartinis režimas turi būti keičiamas parenkant optimalias vaistų dozes ir vartojimo dažnumą. Kai kurie TB sergantys ligoniai gydymą nutraukia savavališkai, girtuokliauja. Gydyt tenka pradèti iš naujo po tam tikro laiko. Amerikos krūtinès ląstos ir Amerikos infekcinių ligu draugijų bei ligų kontrolès centras pateikia algoritmą, kaip gydyti

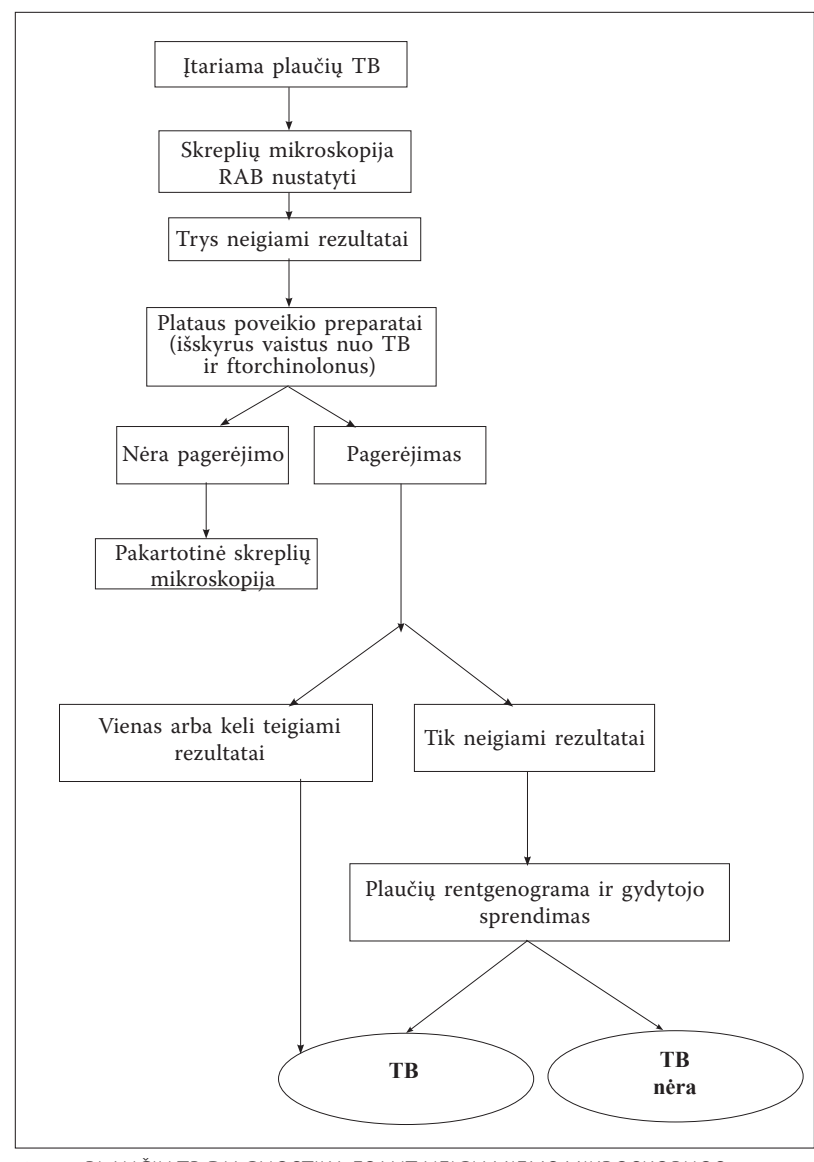

1 pav. PLAUČIU TB DIAGNOSTIKA ESANT NEIGIAMIEMS MIKROSKOPIJOS REZULTATAMS [7] 


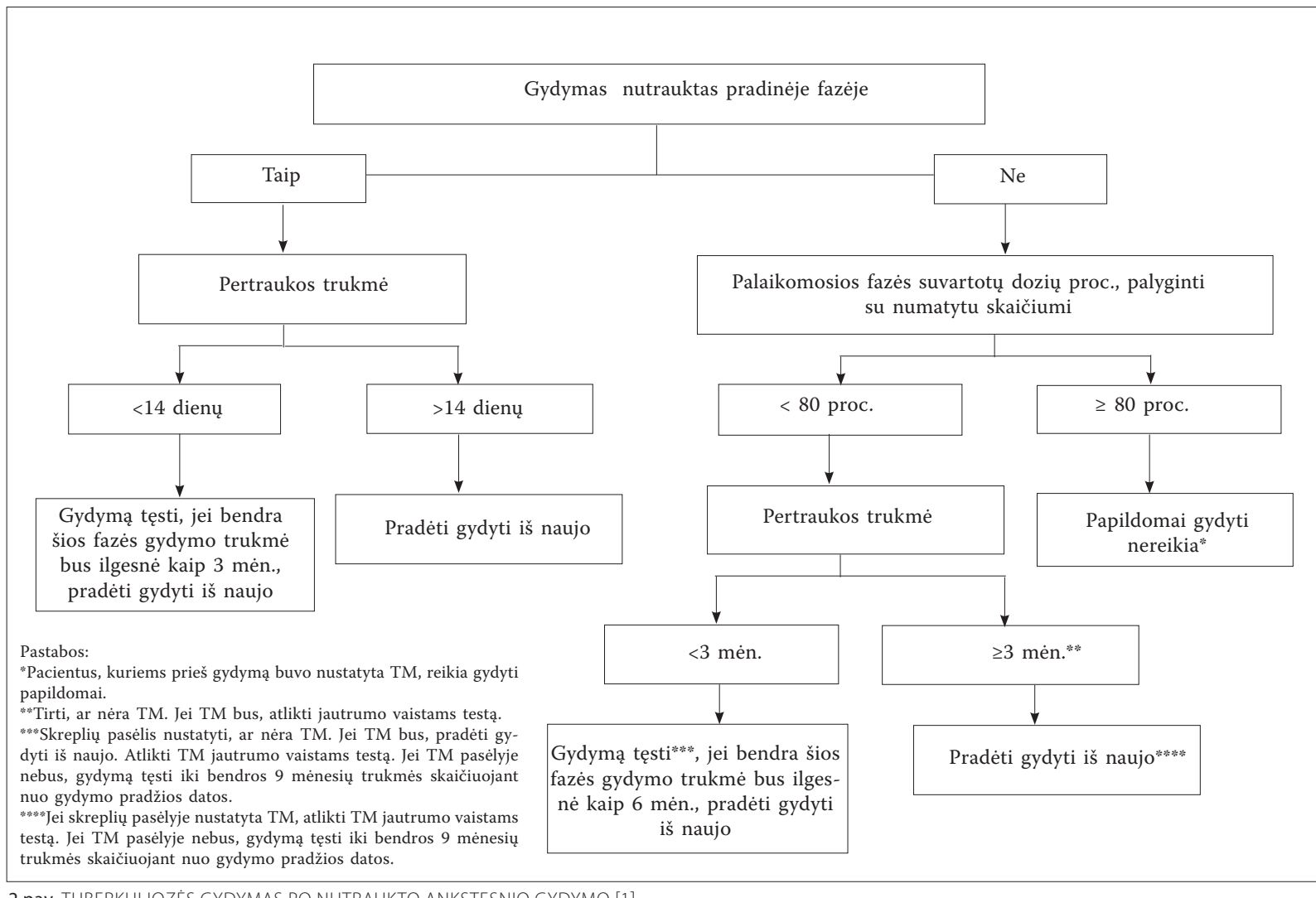

2 pav. TUBERKULIOZĖS GYDYMAS PO NUTRAUKTO ANKSTESNIO GYDYMO [1]

TB po nutraukto ankstesnio gydymo (2 pav.).

Ivertinami trys pagrindiniai veiksniai: gydymo pertraukos trukmé, TM išskyrimas, skirto gydymo trukmè (proc.)

Kad TB gydymas būtu sékmingas, jis turi būti kontroliuojamas ir nepertraukiamas, o tai labai priklauso nuo paciento ir gydančiojo gydytojo partnerystés. Laikytis gydymo režimo - sunkus uždavinys ligoniui, kadangi gydymas trunka gana ilgai, ne trumpiau kaip 6 mèn., nors ir jaučiamasi labai gerai. Ilgalaikis gydymo kursas sutrikdo ịprastą ligonio gyvenimo ritmą, jo nusistovejusius ipročius.

5 pagrindiniai veiksniai, turintys reikšmės gydymosi režimui ir jo rezultatams:

- Socialiniai ekonominiai veiksniai - tai socialiniu reikmiu i̇vertinimas, paciento gyvenamojo būsto problemų sprendimas, sudarymas sąlygų atvažiuoti ì gydymo įstaigą nemokamai, materialinè pagalba, šeimos nariu ir visuomenès geranoriškumas $\mathrm{TB}$ ligoniư atžvilgiu.

- Veiksniai, susiję su sveikatos apsaugos sistema, - medicinos personalo kontrolè ir mokymas, kad būtu garantuotas kokybiškas gydymo režimas, tiesiogiai kontroliuojamo gydymo vykdymas.

- Ligonio būklès veiksniai - specifinè narkomanu psichologija, depresija, emocinè ittampa.

- Gydymo veiksniai - sudètingas gydymo režimas, šalutinis vaistų poveikis; informavimas apie galimą vaistų poveiki, gydymo režimo laikymasis, nuolatinè kontrolè.

- Nuo paciento priklausantys veiksniai - nepalankūs: narkomanija, depresija, emocinè įtampa; palankūs: tikejjimas gera ligos baigtimi, motyvacija pasveikti, ligonio ir gydytojo partnerystės svarba gydymosi laikotarpiu.

$\mathrm{TB}$ sergančiu pacientu gydymo veiksmingumas ir sèkmè priklauso nuo daugelio veiksnių: socialinių ekonominių, sveikatos priežiūros įstaigų darbo organizavimo, medicinos personalo veiksmų, o svarbiausia - nuo paties ligonio apsisprendimo gydytis nepažeidžiant gydymo režimo.

Ligonio gydymo veiksmingumo stebėsena ir gydymo kontrolè - skirtingi dalykai. Stebèti pacientą būtina norint ịvertinti gydymo veiksmingumą, o kontroliuoti gydymą - siekiant i̇sitikinti, kad pacientas tikrai vartoja vaistus. Tiesiogiai kontroliuojamo gydymo strategija tebèra pati svarbiausia gydant TB sergančius ligonius.

\section{TB DIAGNOSTICS AND TREATMENT \\ VIDA BUTKUVIENE \\ DEPARTMENT OF PULMONOLOGY AND IMMUNOLOGY KAUNAS UNIVERSITY OF MEDICINE}

Key words: TB diagnostics and treatment.

Summary: The role of family doctor in recognition of TB (tuberculosis) ill patients is very important. Negative social factors, addictions, chronic diseases, other infections, malnutrition increase the possibility of developing TB. Evaluation of TB criteria is essential in TB confirmation. The main attention must be payed to ethiologic diagnostics and directly observed treatment (DOTS). Doctors of different specialities: phthysiatrists, pulmonologists, internists, especially doctors of general practice must participate in process of TB diagnostics and treatment. Appropriate treatment is the main preventive measure of TB. DOTS strategy based on ethiologic TB diagnostics and standartised chemotherapy is the main strategy of TB treatment.

Literatūros šaltiniai - redakcijoje (iš viso 8). 